Pavlyuk Tetiana, $\mathrm{PhD}$ in Economics, Associate Professor, Vinnitsa Institute of Trade Economics of Kiev National University of Trade and economics,

Vinnitsa, Ukraine

ORCID 0000-0002-5417-6250

Researcher ID C-4426-2018

\title{
INTERNATIONAL TRADE DEVELOPMENT TRENDS
}

The main trends of development of international trade in services are considered in the article. It is determined that the development of international trade in services is a prerequisite for the development of the entire economy of any country in the world. A number of factors that have a decisive influence on the development of the international service sector are analyzed. Exports-imports of services in the world and Ukraine are projected.

Keywords:international trade, world market, service market, export, import.

\section{Павлюк Тетяна. Міжнародні тенденції розвитку торгівлі.}

У статті розглянуто основні тенденції розвитку міжнародної торгівлі послугами. Визначено, що розвиток міжнародної торгівлі послугами $\epsilon$ необхідною умовою розвитку всієї економіки будь-якої країни світу. Проаналізовано низку факторів, що мають вирімальний вплив на розвиток сектора міжнародних послуг. Прогнозується експорт-імпорт послуг у світі та Україні.

Ключові слова: міжнародна торгівля, світовий ринок, ринок послуг, експорт, імпорт.

Relevance of the research topic.In the context of the globalization of the world economy, the level of socio-economic development of individual countries depends to a large extent on the foreign economic sector. International turnover of goods and services is increasing, the movement of capital and financial resources is accelerating. A characteristic feature of the current stage of development of the world market is the rapid growth of services trade, which is caused by rapid technological changes, intellectualization of labor, informatization of social and industrial relations. The directions of foreign trade flows and the type of structure of the services market are constantly changing. The volume of related services in the production and export 
of many capital and high-tech goods (software, design, engineering, logistics, marketing services) is increasing; services, hotel, advertising, consulting, insurance, financial, agency, brokerage, law and leasing services, franchising, licenses and patents, know-how, and more are gaining in importance.

Formulation of the problem. The services market is becoming one of the most promising sectors of the world market. In the structure of the balance of payments of individual countries, the share of the services sector is about $20 \%$, and it itself becomes the largest recipient of international investment. The functioning of the services market in each country has its own peculiarities, since its specialization in certain types of services depends on the level of economic development and the available competitive advantages. Exploring these features is important for developing strategies and programs for specific markets.

Analysis of recent research and publications. Problems of functioning of the Ukrainian market of services and evaluation of its effectiveness are devoted to the scientific works of I. Burakovsky, V. Zaitsev, I. Kalachova, M. Lesnikov, A. Mazaraki, Y. Melnyk, N. Meshko, V. Mikhailova, A. Olefir, V. Tipanova, T. Tsygankova, T. Sheremet and others. However, in their work, insufficient attention has been paid to the study of structural changes, general trends in the development of international trade in services, and Ukraine's participation in this process.

Presenting main material.The development of international trade in services is a prerequisite for the development of the entire economy of any country in the world. Under the influence of the processes of liberalization, integration and globalization in the modern world economy, there is an active development of the sphere of services in most countries of the world. Practice shows that it is one of the most important and growing components of the world economy. It can even be stated that the services market is to a large extent a dynamizer of world production, scientific and technological progress and the whole system of international economic relations. And the model of the world economy, which is formed under the influence of modern information-technological and globalization tendencies, is often called «service economy». Thus, in developed countries, the share of services in GDP exceeds $70 \%$, accounting for about $65 \%$ of the working population of the planet (in the USA - up to $75 \%$ ).

In today's market conditions, both for any country and for Ukraine, international economic activity, in particular trade in services, is of great importance. In the Ukrainian economy, as in the whole world, the role of the service sector is growing. The number of services, their variety and quality, the impact on people's lives is increasing, the number of commercial-intermediary structures is increasing, which provide multifaceted needs for production and non-production services.

Today, the international market for services, as a sectoral commodity market, is not yet an organic system; This is evidenced by processes and phenomena such as imbalances in long-term supply and demand in many industries, significant differences in 
tariffs for the same types of services, the absence of a global system for regulating trade in services, and a unified classification of services as it exists in commodity trade.

By looking at the annual trade reports of the World Trade Organization, we can see a trend of steady increase in international trade flows over the last three decades. For example, according to WTO trade statistics from the most recent reports, the value of world exports of services has increased from $\$ 367$ billion in 2012 to 4.17 trillion. dollars in 2017 , or 8.2 percent a year. In physical terms, international trade has shown a more than fourfold increase from 2012 to the present. Services have become a major sector of economic activity and a source of employment in the global economy. Based on the research, prerequisites and patterns of development of the global services market, it is possible to identify a number of factors that have a decisive impact on the development of the international service sector (Table 1).

Table 1

\section{Main factors for the development of the international services market [8]}

\begin{tabular}{|l|l|l|}
\hline \multicolumn{1}{|c|}{$\begin{array}{c}\text { The driving force behind } \\
\text { international trade } \\
\text { in services }\end{array}$} & $\begin{array}{l}\text { The main factors driving the growth of } \\
\text { the international services market }\end{array}$ & $\begin{array}{l}\text { The service sector, } \\
\text { whose development is } \\
\text { facilitated by a factor }\end{array}$ \\
\hline $\begin{array}{l}\text { Availability of quality } \\
\text { human capital }\end{array}$ & $\begin{array}{l}\text { Increasing the role of knowledge and } \\
\text { business skills as a source of profit }\end{array}$ & $\begin{array}{l}\text { Business, management, } \\
\text { professional and } \\
\text { educational services }\end{array}$ \\
\hline $\begin{array}{l}\text { Investments in intangible } \\
\text { assets }\end{array}$ & Privatization / deregulation / outsourcing & $\begin{array}{l}\text { Financial, business } \\
\text { services }\end{array}$ \\
\hline $\begin{array}{l}\text { Efficiency of internal } \\
\text { regulation }\end{array}$ & Urban growth and urbanization & All types of services \\
\hline $\begin{array}{l}\text { The quality of the } \\
\text { institutional environment }\end{array}$ & $\begin{array}{l}\text { Application of innovations in the services } \\
\text { sector, which has led to cheaper services } \\
\text { due to economies of scale, better } \\
\text { understanding of customer needs, } \\
\text { application of research results, } \\
\text { international service creation }\end{array}$ & $\begin{array}{l}\text { Transport, business, } \\
\text { telecommunication, } \\
\text { tourist services }\end{array}$ \\
\hline $\begin{array}{l}\text { National policy on } \\
\text { international trade in } \\
\text { services }\end{array}$ & $\begin{array}{l}\text { The share of multinational services is } \\
\text { increasing }\end{array}$ & All types of services \\
\hline
\end{tabular}

Characteristic features of the current stage of development of the world economy are the tendencies of internationalization, transnationalization and globalization, which certainly influenced the development of international trade in services. For the sake of generating additional profits, gaining positive economies of scale, national companies in the developed and individual new industrial countries are expanding their operations, gradually moving beyond their national economies. 
Thus, transnational corporations specializing in the production and sale of services, which either accompany commodity trade (tuning, maintenance of equipment, transportation, etc.) are formed, or exist separately, meeting the needs of both production and non-production. sectors (computer services, tourism, insurance, etc.). In addition, globalization, reflected primarily in the intensification of scientific and technological progress, is accelerating the international exchange of certain types of services, including financial services. All this directly affects the dynamics of the world economy.

Modern international trade in services is characterized by the following development trends:

- stable rates of economic development and growth;

- enhancing the role of international trade in services in the basis of development and formation of the world economy;

- the growing importance of the service sector for the world economy (the share of foreign trade in services is the most dynamic, since a significant number of services are market goods and are in high demand and are also recorded in the balance of payments operations of the country as a whole);

- development of integration processes at the regional level.

Current trends in international trade in services are driven by the dynamics of social division of labor and the increasing number of people employed in this field. At the present stage of international trade the following features of development are inherent:

- a significant expansion of the global exchange of services;

- there is a tendency of rising prices in the world market;

- increasing role of developed countries in international trade;

- deepening of non-equivalent exchange;

- increasing the share of services in world trade. The main trend in the development of the global services market in recent years has been the growing importance of developing countries in the production, export and import of services. In the last two decades, in some developing countries, the revenues generated by exports of services, the number of employees in the sector, and the foreign exchange earnings from services exports have increased significantly. Increasing the volume of trade in services allows to increase production capacity and develop trade and transport infrastructure. Low-cost and high-quality services have a positive effect on the economy as a whole.

In the context of the dynamic global competitive environment, the services sector becomes dynamic and becomes one of the influential factors on which the economic growth, increasing the country's competitiveness in world markets, and improving the well-being of the population depend. 
According to the forecast, the volume of exports and imports of services in the world by 2025 will have a negative trend.

One can trace the overall downward trend in exports and imports of services in the global market due to certain sectors being hit by the global crisis. Therefore, the international market for services is now a complex multilevel system that continues to evolve in the face of economic globalization. A further perspective on the development of this market lies in the development of a system of foreign economic relations between large international associations and organizations. Integration processes in the world contribute to the creation of common mechanisms for regulating the market of services in the world, which leads to the intensification of foreign trade relations between countries, and further elimination of barriers to international trade.

The Ukrainian market for services is still underdeveloped, with a rather narrow range of sectors in which activity and development are observed. In the telecommunications and financial services sectors, capital availability is of great importance. In the financial services industry, a considerable number of relatively small banks operate. The weakness of financial intermediation institutions and infrastructure in the telecommunications sector creates impediments to economic growth and does not facilitate the rapid introduction of new technologies. Foreign investment in these sectors can bring more promising, cost-effective technologies. Due to technological capabilities and potential in aircraft and shipbuilding, Ukraine has good prospects for development.

Since Ukraine's membership in the World Trade Organization, many changes have occurred, namely in the development of its international trade in services. There has been an increase in labor productivity through trade liberalization, that is, an increase in the competitiveness of the national economy. These changes are longlasting and have a major impact on the country's economy. We can also see improvements in Ukraine's performance in international trade in services (according to the index of countries' participation in international trade). If you look at the ranking of The Global Enabling Trade Index 2016, Ukraine ranks 95th out of 183. According to the experts of the World Economic Forum, Ukraine has improved the level of administrative management at the borders (was 116th place and 100th) and the level of development of transport and communication infrastructure. (from 64 to 61 places).

Priority directions of development of the international market of services of Ukraine are:

- attraction of foreign investments on the basis of creation of joint ventures, free economic zones, other forms of joint venture with foreign capital;

- formation of an extensive system of foreign economic management (banks, stock exchanges, consulting companies, audit, leasing); 
- creation of flexible tax, price, deposit, credit, financial and monetary policies that stimulate diversification of export-import operations;

- creation of a strong export sector;

- gradual integration of the economy into European and world organizations;

- support of close cooperation with industrially developed ones states. [3]

In order to develop the service sector in Ukraine, it is necessary to involve as much foreign investment in this sphere as possible, which in turn will contribute not only to capital inflows, but also to new, technically efficient methods of service delivery, which will help to improve the quality of services and their accessibility. It is also important to increase the competitiveness of domestic services and strengthen Ukraine's position in the international market for services, which is possible, in particular, in the context of an improved service culture. Ukraine has great prospects in international trade in services, the priority of which should be the active development of exports and the improvement of international trade relations between countries. The fulfillment of the above tasks will give Ukraine a worthy place in the world market and ensure the implementation of the set integration intentions for the international economy.

A forecast was made for a drop in exports and imports of services to Ukraine by 2025. This forecast is caused by the difficult economic situation, political instability, inflationary processes and war in the East of the country.

The main obstacles to the expansion and diversification of Ukrainian export of services are the problems of internal nature: lack of adequate regulatory framework, effective taxation systems, favorable investment and innovation climate, insufficient development of small and medium-sized enterprises, etc.

In general, the Ukrainian service industry is characterized as being in the process of development. This state of affairs requires a balanced approach to the strategy of development, regulation and especially liberalization of the service sector, the proper consistency of this process. The stage, directly related to liberalization, should provide for the preliminary creation of a unified system of state regulation and the development of competition in the markets. The main objective of these measures should be to provide potential market participants with free access to the service markets and to exclude discrimination against foreign market participants in comparison with residents. At the same time, it is necessary to strengthen the domestic potential of the offer and increase its competitiveness.

The effective functioning of the Ukrainian service sector should also be directly linked to the development of a long-term public program for its continued sustainable development, identifying key and promising sectors that need immediate support. This is especially true of the technology sector. At present, the structure of Ukrainian exports is dominated by $\mathrm{t}$ services, which are relatively low-dynamic and are characterized by a decline in their own share in global sales (first of all, transport 
services). At the same time, the increase in the export structure of the share of «other commercial services», which includes services that, by definition of the Organization for Economic Cooperation and Development, are considered high-tech, should become a priority task in forming a promising model of Ukraine's international specialization.

Dynamic development of the services market in Ukraine is possible only if an effective state policy is implemented and a carefully grounded export-import strategy is formed, which will help to increase the competitiveness of the industry in the global services market.

Conclusion. Thus, Ukraine needs to use the accumulated experience of leading market economies. It is this experience that can be used, adapted, adapted to the specific conditions and realities of Ukraine. After all, establishing economic cooperation with leading countries of the world brings domestic services to powerful, demanding and rigid modern markets, competition in which will force our entrepreneurs to seek a new level with cost, quality and marketing. Expanding and deepening contacts with industrialized nations, their entrepreneurs and businessmen will facilitate the development of international trade in services in Ukraine International trade in services is currently an important area of the global economy, as its impact on global economic development is increasing. Due to global trade in services, the pace of economic development in general is increasing. Ukraine has great prospects in international trade in services, the priority of which should be the active development of exports and the improvement of international trade relations between countries. The state has the potential to develop many service sectors, including tourism, engineering and construction services, transport services (river, sea, aviation, road, space, rail) and more. Today, Ukraine has chosen the European vector for foreign trade in services and its perspective and main partners in this field are EU countries.

Having analyzed the multifaceted nature of international trade in services, global trade in services is at the forefront of the development of each country. Through international trade, countries can develop several areas of activity in which they specialize well or import those services that they do not have or do not produce, or which are of comparable quality to other countries. Priority areas for the development of global trade in services include the following: development of intellectual services, scientific and technological progress; information boom; growth and increase in the number of service providers; accelerated development of modes of transport; an increase in the share of new types of services, including insurance services, banking, intermediation, etc.; know-how, or new scientific discoveries. 


\section{REFERENCES}

1. Derzhavna sluzhba statystyky Ukrainy. [State Statistics Service of Ukraine] URL: http://www.ukrstat.gov.ua/ (accessed June 17, 2019).

2. Lukianenko D., Kolesov V., Kolot A. (2013). Hlobalnoe эkonomycheskoe razvytye: tendentsyy, asymmetryy, rehulyrovanye [Global economic development: trends, asymmetries, regulation] : monohrafyia KNEU, $466 \mathrm{p}$.

3. Spivrobitnytstvo mizh Ukrainoiu ta krainamy YeS u 2017 r. (2018) [Cooperation between Ukraine and EU countries in 2017]: statystychnyi zbirnyk. Derzhavna sluzhba statystyky Ukrainy, № 6. p.195.

4. Statystychni dani pro obsiahy zovnishnoi torhivli [Foreign trade statistics] URL: http://epp.eurostat.ec.europa.eu/ (accessed June 17, 2019).

5. Strekal O. V. Krainy Zakhidnoi Yevropy ta problemy yevropeiskoi intehratsii. [Strekal OV Western European countries and problems of European integration]. URL: www.niss.gov.ua. (accessed June 17, 2019).

6. Tokhtamysh T. O., Yaholnytskyi O. A., Ovchynnikova M. A. (2018). Teoretychni aspekty orhanizatsii zovnishnoi torhivli Ukrainy $\mathrm{z}$ krainamy Yevropeiskoho Soiuzu. [Theoretical aspects of the organization of foreign trade of Ukraine with the countries of the European Union.] Problemy systemnoho pidkhodu $v$ ekonomitsi Vyp. 2. p. 7-12. URL: http://nbuv.gov.ua/UJRN/PSPE_print_2018_2_3 (accessed June 17, 2019).

7. The Trade and Development Report URL: http: unctad.org/en/ Publications Library/tdr2014_en.pdf. (accessed June 17, 2019).

8. World trade statistics URL: http: www.wto.org - Vsesvitnia orhanizatsiia torhivli (accessed June 17, 2019). 